\title{
PERBEDAAN KADAR KOLESTEROL TOTAL DAN TRIGLISERIDA PADA WANITA VEGETARIAN TIPE VEGAN DAN NON-VEGAN
}

\author{
Mira Rizky Pamungkas, Ani Margawati ${ }^{*}$ \\ Program Studi Ilmu Gizi Fakultas Kedokteran Universitas Diponegoro \\ Jl.Dr.Sutomo No.14, Semarang, Telp (024) 8453708, Email : gizifk@undip.ac.id
}

\begin{abstract}
Background : Non-vegan vegetarian women had higher risk in higher levels of total cholesterol and triglyceride than vegan. This is related to animal product such as milk, eggs, and other dairy product that they consumed. In addition, the age factor, duration of vegetarian diet, body mass index (BMI), and physical activity are factors that can't be ignored.

Methods : This study was a qualitative and quantitative cross sectional study. All 19 non-vegan diet and 19 vegan diet subjects were consecutive sampling chosen. Data collected were BMI, nutrient intake, physical activity, total cholesterol and triglycerides levels, and qualitative data of feeding behavior. Independent t-test used for variables age, BMI, carbohydrate and fat intake as bivariate analyze, while Mann-Whitney test for variables duration of vegetarian, physical activity, saturated fat intake, cholesterol, MUFA, PUFA, and total fiber. Multivariate analyze using ANCOVA test.

Results : There is no significant difference in total cholesterol $(p=0.073)$ and triglycerides $(Z=-0.146 ; p=0.884)$ between vegan and non-vegan women. Total cholesterol and triglycerides among vegan group and non-vegan group were significantly different $(p<0,05)$ for age adjustment, whereas total cholesterol and triglycerides shows no significant differences $(p>0,05)$ based on the type of vegetarian in ANCOVA test.

Conclusions : There were no significant differences in total cholesterol and triglycerides among vegan and nonvegan women but there were significant difference in BMI among vegan and no-vegan. Age was the only variable that affects the control of total cholesterol and triglycerides in both vegan and non-vegan diet. Total cholesterol level and triglycerides of vegan women lower than non-vegan. Since becoming vegetarian, both vegan and nonvegan stated never again and don't want to consume animal products to a various reasons such as feeling healthier without eating animal products, feel that animal products is not their foods and feel nauseous and want to vomit when smell fishy from animal products.
\end{abstract}

Keyword : total cholesterol level; triglyceride; vegan; non-vegan

\begin{abstract}
ABSTRAK
Latar Belakang : Wanita vegetarian non-vegan berisiko memiliki kadar kolesterol total dan trigliserida yang tinggi dibandingkan dengan vegan. Hal tersebut berkaitan dengan vegetarian non-vegan masih mengkonsumsi produk hewani antara lain susu, telur dan produk olahannya. Selain itu, faktor usia, lama menjadi vegetarian, indeks massa tubuh (IMT), aktivitas fisik menjadi faktor yang tidak dapat diabaikan.

Metode : Desain penelitian cross sectional dengan pendekatan kuantitatif kualitatif. Jumlah sampel terdiri dari 19 vegetarian vegan dan 19 non-vegan yang dipilih secara consecutive sampling. Data yang diambil adalah IMT, asupan zat gizi, aktivitas fisik, kadar kolesterol total dan trigliserida serta data kualitatif perilaku makan. Analisis bivariat menggunakan uji independent t-test untuk variabel usia, IMT, asupan karbohidrat dan lemak total sedangkan uji Mann-Whitney untuk variabel lama menjadi vegetarian, aktivitas fisik, asupan lemak jenuh, kolesterol, MUFA, PUFA serta serat total. Analisis multivariat menggunakan uji ANCOVA (Analysis of Covariance).

Hasil : Tidak terdapat perbedaan yang signifikan kadar kolesterol total $(p=0,073)$ dan trigliserida $(Z=-0.146$; $p=0,884)$ antara wanita vegan dan non-vegan. Berdasarkan uji ANCOVA perbedaan kolesterol total dan trigliserida antara kelompok vegan dan non-vegan lebih bermakna berdasarkan variabel usia $(p<0,05)$, sedangkan kolesterol total dan trigliserida tidak menunjukkan perbedaan yang signifikan berdasarkan tipe vegetarian $(p>0,05)$.

Simpulan : Tidak terdapat perbedaan yang signifikan kadar kolesterol total dan trigliserida antara wanita vegetarian vegan dan non-vegan tetapi terdapat perbedaan yang signifikan IMT antara vegan dan non-vegan. Usia merupakan satu-satunya variabel kontrol yang berpengaruh pada kadar kolesterol total dan trigliserida baik pada vegan maupun non-vegan. Kadar kolesterol total dan trigliserida pada kelompok vegan lebih rendah dibandingkan non-vegan. Sejak menjadi vegetarian, baik pada kelompok vegan maupun non-vegan menyatakan tidak pernah dan tidak ingin lagi mengkonsumsi produk hewani dengan berbagai alasan antara lain merasa lebih sehat tanpa makan
\end{abstract}

${ }^{*}$ Penulis Penanggungjawab 
produk hewani, merasa bahwa produk hewani tersebut bukanlah makanannya dan merasa mual serta ingin muntah saat mencium bau amis dari produk hewani tersebut.

Kata kunci : kadar kolesterol total; trigliserida; vegan; non-vegan

\section{PENDAHULUAN}

Vegetarian telah berkembang pesat selama bertahun-tahun yang berawal dari suatu kebutuhan hingga menjadi suatu pilihan dan kini mulai menjadi gaya hidup di masyarakat Indonesia. Berdasarkan survei pada tahun 2006, sekitar 4,8 juta $(2,3 \%)$ penduduk dewasa di Amerika menjadi vegetarian dan sekitar $1,4 \%$ menjadi vegan (vegetarian murni). ${ }^{1}$ Jumlah vegetarian di Indonesia yang terdaftar pada Indonesia Vegetarian Society (IVS) saat berdiri pada tahun 1998 sekitar 5.000 anggota dan meningkat menjadi 60.000 anggota pada tahun $2007 .^{2}$

Diet vegetarian mempunyai banyak manfaat kesehatan, antara lain mencegah dan melindungi seseorang dari berbagai penyakit kronik, seperti jantung koroner, kanker, osteoporosis, diabetes, kelainan syaraf dan menurunkan risiko obesitas serta tekanan darah tinggi. Hal tersebut diyakini karena diet vegetarian kaya akan lemak tak jenuh (MUFA dan PUFA), antioksidan, serat dan rendah kolesterol serta rendah lemak jenuh.-7 Dibandingkan tipe vegetarian yang lain, vegan cenderung rendah lemak jenuh dan kolesterol serta tinggi serat karena tidak mengkonsumsi produk hewani sama sekali. ${ }^{8}$

Penyakit jantung koroner (PJK) merupakan penyebab kematian utama di negara maju dan negara berkembang yang diprediksikan akan menjadi penyebab kematian nomor satu di dunia pada tahun 2020. ${ }^{4}$ Salah satu biomarker untuk mengetahui faktor risiko PJK adalah pengukuran profil lipid. Konsentrasi serum kolesterol total merupakan faktor risiko biokimia sangat penting untuk PJK. Menurut National Cholesterol Education Program Adult Treatment Panel III (NCEP ATP III), penurunan 10\% kolesterol total akan menurunkan risiko kejadian PJK sebesar $30 \%$ dan berdasarkan beberapa studi epdemiologi prospektif diketahui adanya hubungan positif antara kadar trigliserida dengan kejadian PJK. ${ }^{9}$ Faktor risiko yang terkait dengan serum kolesterol total dan trigliserida yang tinggi yaitu usia, asupan zat gizi (tinggi karbohidrat, lemak total, lemak jenuh dan kolesterol serta rendah serat), obesitas, kebiasaan merokok, serta rendahnya aktivitas fisik. ${ }^{4,10}$

Vegetarian non-vegan masih mengkonsumsi produk hewani yang meliputi telur, susu dan produk olahannya. Telur, susu dan produk olahannya tersebut mengandung lemak jenuh dan kolesterol serta jika dikonsumsi secara berlebihan maka akan dapat meningkatkan kadar kolesterol total. ${ }^{9,10}$ Pada vegetarian vegan konsumsi lemak jenuh dan kolesterol tergolong rendah. ${ }^{8}$ Karbohidrat akan berperan sebagai pengganti lemak jenuh pada kelompok vegan sehingga asupannya akan lebih tinggi. Hal tersebut akan meningkatkan kadar trigliserida. Namun, saat karbohidrat dikonsumsi bersamaan dengan asupan kaya serat, peningkatan kadar trigliserida tersebut dapat menurun. ${ }^{9,10}$ Beberapa penelitian diketahui kelompok vegetarian memiliki kadar kolesterol total dan trigliserida lebih rendah dibandingkan non-vegetarian dan vegan memiliki kadar kolesterol total serta trigliserida terendah. ${ }^{11-13}$ Namun, pada penelitian lain di Bali diketahui kadar kolesterol total dan trigliserida vegan justru lebih tinggi dibandingkan dengan lakto vegetarian dan lakto-ovo vegetarian. ${ }^{14}$ Penelitian lain pada vegetarian lansia diketahui kadar kolesterol total dan trigliseridanya lebih tinggi dibandingkan nonvegetarian. ${ }^{15}$ Hal tersebut menunjukkan usia juga sangat berperan dalam peningkatan kadar kolesterol total dan trigliserida meskipun asupan lemak jenuh dan kolesterol tergolong rendah. Lama seseorang vegetarian berhubungan dengan kualitas dan kuantitas asupan zat gizi yang dapat mempengaruhi kadar kolesterol total dan trigliserida. Diet vegetarian yang dijalani $\geq 12$ tahun memiliki kadar kolesterol total lebih rendah dibandingkan diet vegetarian yang dijalani 6-11 tahun. Namun, lama vegetarian tersebut tidak berpengaruh signifikan terhadap kadar trigliserida. Kadar trigliserida terendah dimiliki oleh subjek yang menjalani diet vegetarian $<6$ tahun sedangkan diet vegetarian selama 6-11 tahun diketahui memiliki kadar trigliserida tertinggi. ${ }^{11}$

Berdasarkan latar belakang tersebut, peneliti tertarik untuk mengetahui perbedaan kadar kolesterol total dan trigliserida pada wanita vegetarian vegan dan non-vegan.

\section{METODE}

Penelitian ini termasuk dalam lingkup gizi masyarakat dengan desain cross sectional dan dengan pendekatan kuantitatif serta kualitatif. Data kualitatif digunakan sebagai konfirmasi untuk 
memperkuat data kuantitatif. Penelitian berlangsung pada bulan Juni hingga Juli 2012 di beberapa kota, diantaranya Surabaya, Semarang dan Yogyakarta. Sebagian besar subjek yang diambil terdaftar sebagai anggota IVS di wilayah masing-masing dan sisanya berasal dari komunitas SUMA Ching Hai (suatu komunitas meditasi yang menganut pola makan vegetarian). Besar subjek dalam penelitian ini 38 subjek (19 subjek pada masing-masing tipe vegetarian) yang dihitung menggunakan rumus besar sampel untuk beda rerata dua kelompok tidak berpasangan dengan tingkat kemaknaan $\left(\mathrm{Z}_{\alpha}\right) 95 \%$, tingkat kekuatan uji $\left(Z_{\beta}\right)$ 1,64, simpang baku kedua kelompok (S) 29,5 dan perbedaan klinis yang diinginkan $\left(\mathrm{x}_{1}-\mathrm{x}_{2}\right)$ $34,26 .{ }^{12}$ Subjek diambil secara consecutive sampling setelah memenuhi beberapa kriteria yaitu wanita berusia $\geq 20$ tahun, tidak mengkonsumsi obat anti-hiperlipidemia minimal tiga bulan terakhir, tidak merokok, tidak sedang menderita atau memiliki riwayat penyakit degeneratif (penyakit kardiovaskuler, hati, diabetes mellitus dan ginjal) serta tidak sedang hamil.

Variabel bebas dalam penelitian ini adalah tipe vegetarian. Subjek dinyatakan vegetarian tipe vegan bila hanya mengkonsumsi makanan nabati dan tidak pernah lagi mengkonsumsi makanan hewani serta produk yang berasal dari sumber hewani (madu, susu, telur dan olahannya) sedangkan dinyatakan non-vegan bila mengkonsumsi makanan nabati, tidak pernah lagi mengkonsumsi makanan hewani tetapi masih mengkonsumsi susu, telur beserta hasil olahannya. Olahan yang dimaksud adalah produk yang berupa kue, biskuit, roti dan lain-lain. Dalam penelitian ini, batasan produk olahan makanan antara vegan dan non-vegan dipisahkan dengan jelas yaitu produk olahan akan dimasukkan sebagai makanan vegan apabila produk tersebut diolah sendiri oleh subjek vegan atau jika diperoleh dari luar (membeli) hanya berasal dari penjual khusus makanan vegan. Sebagian besar subjek vegan pada penelitian ini memperoleh produk olahan dari restoran vegetarian yang khusus menyediakan makanan vegan, sehingga komposisi dari produk tersebut dapat terjamin bebas dari susu atau telur, karena pada umumnya pengelola restoran vegetarian tersebut juga termasuk penganut vegetarian vegan. Sebaliknya, produk olahan akan dimasukkan ke dalam makanan non-vegan apabila subjek memperoleh produk tersebut dari penjual luar yang bukan penganut vegetarian (produk pasaran) yang komposisi bahan makanannya tidak bisa dijamin.
Variabel perancu dalam penelitian ini adalah usia, lama menjadi vegetarian, IMT, aktivitas fisik dan asupan zat gizi (karbohidrat, lemak total, lemak jenuh, MUFA, PUFA, kolesterol dan serat total). Data usia dan lama menjadi vegetarian diperoleh melalui wawancara dengan subjek. Deskripsi usia dalam tabel distribusi frekuensi dikategorikan menjadi 20-29 tahun, 30-39 tahun, 40-49 tahun, 50-59 tahun dan $\geq 60$ tahun. $^{16}$ deskripsi lama menjadi vegetarian dalam tabel distribusi frekuensi dikategorikan menjadi < 6 tahun, 6-11 tahun dan > 11 tahun. ${ }^{11}$ Data IMT diperoleh melalui perbandingan hasil pengukuran berat badan $(\mathrm{kg})$ dan kuadrat tinggi badan (m). Berat badan diukur menggunakan timbangan digital dengan kapasitas $150 \mathrm{~kg}$ dan ketelitian $0,1 \mathrm{~kg}$ sedangkan tinggi badan diukur menggunakan microtoise dengan kapasitas $200 \mathrm{~cm}$ dan ketelitian $0,1 \mathrm{~cm}$. Deskripsi IMT menurut WHO dikategorikan menjadi underweight $(<18,5$ $\left.\mathrm{kg} / \mathrm{m}^{2}\right)$, normal $\left(18,5-22,9 \mathrm{~kg} / \mathrm{m}^{2}\right)$, overweight $\left(23,0-24,9 \mathrm{~kg} / \mathrm{m}^{2}\right)$, obese I $\left(25,0-29,9 \mathrm{~kg} / \mathrm{m}^{2}\right)$ dan obese II $\left(\geq 30 \mathrm{~kg} / \mathrm{m}^{2}\right){ }^{17}$ Data aktivitas fisik diperoleh melalui wawancara menggunakan International Physical Activity Questionnaire (IPAQ) . Aktivitas fisik yang dilaporkan oleh subjek mencakup kegiatan yang dilakukan selama tujuh hari terakhir. Skor aktivitas fisik dihitung sesuai dengan protokol skoring IPAQ dan dinyatakan dalam satuan MET-menit/minggu kemudian dikategorikan dalam tingkat aktivitas fisik yang rendah (<600 MET-menit/minggu), sedang (600-1499 MET-menit/minggu), dan tinggi $(\geq 1500 \mathrm{MET}-\mathrm{menit} / \mathrm{minggu}){ }^{18}$

Data asupan zat gizi (karbohidrat, lemak total, lemak jenuh, MUFA, PUFA, kolesterol dan serat total) diperoleh melalui wawancara menggunakan formulir Food Frequency Semi Quantitatif (FFSQ). Hasil yang diperoleh kemudian diolah menggunakan program Nutrisurvey. Data asupan karbohidrat, lemak total, lemak jenuh, MUFA dan PUFA disajikan dalam bentuk persentase setelah dibandingkan dengan total asupan energi sedangkan asupan kolesterol disajikan dalam ukuran mg serta asupan serat total dalam ukuran gram. Kategori asupan zat gizi diperoleh dari anjuran NCEP, di mana asupan seseorang dikatakan baik apabila setelah dibandingkan dengan total energi, jumlah asupan karbohidrat mencapai $\leq 60 \%$, lemak total mencapai $25-35 \%$, lemak jenuh mencapai kurang dari $7 \%$, MUFA mencapai $20 \%$, PUFA mencapai $10 \%$. Sementara itu asupan kolesterol dianjurkan kurang dari $200 \mathrm{mg}$ dan asupan serat total 
dianjurkan mencapai 25-30 g. ${ }^{9}$ Data perilaku makan diperoleh melalui wawancara mendalam dengan subjek penelitian menggunakan pedoman wawancara.

Variabel terikat dalam penelitian ini adalah kadar serum kolesterol total dan trigliserida dalam darah. Pengambilan sampel darah dilakukan oleh petugas laboratorium setelah subjek berpuasa selama 8-12 jam. $^{10}$ Analisis sampel darah dilakukan di laboratorium klinik menggunakan metode CHOD/PAP untuk kolesterol total dan tes warna enzimatik untuk trigliserida dengan alat Cobas Mira Analyzer. Deskripsi kadar kolesterol total dan trigliserida dalam tabel distribusi disajikan berdasarkan kategori dari NCEP. Data kadar kolesterol total dikategorikan menjadi diinginkan $(<200 \mathrm{mg} / \mathrm{dl})$, batas tinggi (200-239 $\mathrm{mg} / \mathrm{dl})$ dan tinggi $(\geq 240 \mathrm{mg} / \mathrm{dl})$ sedangkan data kadar trigliserida dikategorikan menjadi normal $(<150 \mathrm{mg} / \mathrm{dl})$, batas tinggi $(50-199 \mathrm{mg} / \mathrm{dl})$, tinggi (200-499 mg/dl) serta sangat tinggi $(\geq 500 \mathrm{mg} / \mathrm{dl}){ }^{9}$

Analisis univariat dilakukan untuk mendeskripsikan setiap variabel yang diteliti dalam bentuk proporsi, rerata (mean) dan simpang baku.
Data-data tersebut diuji kenormalannya menggunakan Shapiro-Wilk. Analisis bivariat dilakukan dengan uji independent t-test yaitu untuk mengetahui perbedaan kadar kolesterol total antara kelompok vegan dan non-vegan, sedangkan uji Mann Whitney untuk mengetahui perbedaan kadar trigliserida kelompok vegan dan non-vegan. Analisis bivariat juga dilakukan untuk mengetahui perbedaan kadar kolesterol total dan trigliserida berdasarkan variabel-variabel kontrol. Analisis multivariat menggunakan uji ANCOVA untuk melihat perbedaan kadar kolesterol total dan trigliserida pada kelompok vegan dan non-vegan setelah dikontrol dengan variabel usia, lama menjadi vegetarian, IMT, aktivitas fisik, asupan karbohidrat, lemak total, lemak jenuh, MUFA, PUFA, kolesterol dan serat total.

\section{HASIL PENELITIAN \\ Karakteristik Subjek Penelitian}

Karakteristik subjek penelitian dapat dilihat berdasarkan usia, lama menjadi vegetarian, pendidikan dan pekerjaan yang ditunjukkan dalam tabel 1.

Tabel 1. Tabel interpretasi subjek penelitian berdasarkan usia, lama menjadi vegetarian, agama dan pendidikan

\begin{tabular}{llcc}
\hline \multirow{2}{*}{ Karakteristik } & Vegan $(\mathrm{n}=19)$ & $\begin{array}{c}\text { Non-vegan } \\
(\mathrm{n}=19)\end{array}$ \\
\cline { 2 - 4 } & & $\mathrm{n}(\%)$ & $\mathrm{n}(\%)$ \\
\hline Kategori usia & $20-29$ & $6(31,6)$ & $4(21,1)$ \\
& $30-39$ & $4(21,1)$ & $5(26,3)$ \\
& $40-49$ & $4(21,1)$ & $3(15,8)$ \\
& $50-59$ & $2(10,5)$ & $5(26,3)$ \\
& $\geq 60$ & $3(15,8)$ & $2(10,5)$ \\
\hline Lama menjadi vegetarian & $<6$ tahun & $15(78,9)$ & $1(5,3)$ \\
& $6-11$ tahun & $3(15,8)$ & $3(15,8)$ \\
& $>11$ tahun & $1(5,3)$ & $15(78,9)$ \\
\hline Agama & Buddha & $8(42,1)$ & $19(100)$ \\
& Non-Buddha & $11(57,9)$ & 0 \\
\hline Pendidikan & SD & $1(5,3)$ & $2(10,5)$ \\
& SMP & $1(5,3)$ & $3(15,8)$ \\
& SMA & $5(26,3)$ & $3(15,8)$ \\
& Perguruan tinggi & $12(63,2)$ & $11(57,9)$ \\
\hline
\end{tabular}

Kelompok vegan berusia lebih muda dibandingkan kelompok non-vegan. Rerata usia kelompok vegan 39,26 $\pm 15,14$ dan 41,42 $\pm 13,5$ pada kelompok non-vegan tetapi perbedaan usia antara subjek vegan dan non-vegan tidak berbeda signifikan $(p=0,646)$. Sebagian besar subjek vegan 
menjalani dietnya $<6$ tahun, lama diet yang dijalani minimal selama satu bulan oleh dua orang subjek dan satu orang subjek sudah menjalani dietnya selama 15 tahun serta nilai mediannya yaitu tiga tahun. Sebagian besar subjek non-vegan menjalani dietnya > 11 tahun, lama vegetarian yang dijalani minimal selama 2,5 tahun dan maksimal 56 tahun serta nilai mediannya yaitu 14 tahun. Sebelum menjadi vegan, beberapa subjek menjalani diet vegetarian yang masih mengkonsumsi produk susu dan telur (lakto-ovo vegetarian) sehingga pada vegan, total lama menjadi vegetarian minimal selama 15 bulan dan maksimal 56 tahun dengan median yaitu 10 tahun. Terdapat perbedaan bermakna lama menjadi vegetarian antara subjek vegan dan non-vegan $(p=0,000)$.

Semua subjek pada kelompok non-vegan beragama Buddha sedangkan 57,9\% pada kelompok vegan beragama non-Buddha yang meliputi agama Kristen, Katholik dan Islam. Pendidikan subjek sebagian besar adalah perguruan tinggi pada masing-masing kelompok.

\section{Indeks Massa Tubuh (IMT) Subjek}

Distribusi Indeks Massa Tubuh subjek dapat dilihat pada tabel 2.

Tabel 2. Distribusi Indeks Massa Tubuh subjek berdasarkan tipe vegetarian

\begin{tabular}{lccc}
\hline \multirow{2}{*}{ Status gizi $\left(\mathrm{kg} / \mathrm{m}^{2)}\right.$} & Vegan $(\mathrm{n}=19)$ & Non-vegan $(\mathrm{n}=19)$ & \multirow{2}{*}{$p$ value } \\
\cline { 2 - 3 } & $\mathrm{n}(\%)$ & $\mathrm{n}(\%)$ & 0,009 \\
Underweight $(<18,5)$ & $3(15,8)$ & 0 & \\
Normal $(18,5-22,9)$ & $9(47,4)$ & $7(36,8)$ & \\
Overweight $\quad(23,0-$ & $5(26,3)$ & $7(36,8)$ & \\
$24,9)$ & & & \\
Obese I $(25,0-29,9)$ & $2(10,5)$ & $4(21,1)$ & \\
Obese II $(\geq 30)$ & 0 & $1(5,3)$ & \\
\hline
\end{tabular}

Hampir separuh vegan berstatus gizi normal dengan rerata IMT $21.414 \pm 2.76 \mathrm{~kg} / \mathrm{m}^{2}$, sedangkan non-vegan sebagian berstatus gizi normal dan overweight dengan rerata IMT 24.205 $\pm 3.43 \mathrm{~kg} / \mathrm{m}^{2}$. Status gizi obese I ditemukan pada kedua kelompok tetapi status gizi obese II hanya ditemukan pada kelompok non-vegan. Terdapat perbedaan bermakna IMT antara vegan dan nonvegan $(p<0,05)$.

\section{Aktivitas Fisik Subjek}

Distribusi frekuensi aktivitas fisik subjek ditunjukkan pada tabel 3 .

Tabel 3. Distribusi frekuensi aktivitas fisik subjek berdasarkan tipe vegetarian

\begin{tabular}{lccc}
\hline \multirow{2}{*}{ Aktivitas fisik } & Vegan $(\mathrm{n}=19)$ & Non-vegan $(\mathrm{n}=19)$ & \multirow{2}{*}{$p$ value } \\
\cline { 2 - 3 } & $\mathrm{n}(\%)$ & $\mathrm{n}(\%)$ & 0,112 \\
\hline Rendah & $7(36,8)$ & $3(15,8)$ & \\
Sedang & $7(36,8)$ & $6(31,6)$ & \\
Tinggi & $5(26,3)$ & $10(52,6)$ & \\
\hline
\end{tabular}

Aktivitas fisik subjek pada kelompok vegan tergolong rendah dan sedang memiliki persentase yang sama $(36,8 \%)$, sedangkan pada kelompok non-vegan lebih dari separuh memiliki aktivitas yang tinggi. Nilai minimum skor aktivitas fisik sebesar 115,5 MET-menit/minggu, maksimum 5544 MET-menit/minggu dengan median sebesar 939 MET-menit/minggu pada kelompok vegan sedangkan pada kelompok nonvegan memiliki nilai minimum skor aktivitas fisik sebesar 346,5 MET-menit/minggu, maksimum 4708,5 MET-menit/minggu dengan median sebesar 1581 MET-menit/minggu. Tidak terdapat perbedaan bermakna aktivitas fisik antara vegan dan non-vegan $(p>0,05)$.

\section{Asupan Zat Gizi Subjek}

Nilai minimum, maksimum,median, rerata dan simpang baku asupan karbohidrat, lemak total, lemak jenuh, kolesterol, MUFA, PUFA dan serat total subjek dapat dilihat pada tabel 4 . 
Tabel 4. Rerata dan simpang baku asupan karbohidrat, lemak total, lemak jenuh, kolesterol, MUFA, PUFA dan serat total subjek

\begin{tabular}{lccc}
\hline \multirow{1}{*}{ Asupan zat gizi } & Vegan $(\mathrm{n}=19)$ & $\begin{array}{c}\text { Non-vegan } \\
(\mathrm{n}=19)\end{array}$ & \\
\cline { 2 - 3 } & Mean $\pm \mathrm{SD}$ & Mean $\pm \mathrm{SD}$ & \\
\hline Karbohidrat $(\%)$ & $68,16 \pm 8,1$ & $70,26 \pm 7,32$ & 0,406 \\
Lemak total (\%) & $18,74 \pm 6$ & $17,84 \pm 5,79$ & 0,643 \\
Lemak jenuh (\%) & $7,67 \pm 3,4$ & $9,1 \pm 3,76$ & 0,194 \\
Kolesterol (mg) & 0 & $30,18 \pm 55,62$ & 0,000 \\
MUFA (\%) & $4,15 \pm 2,21$ & $3,8 \pm 1,93$ & 0,569 \\
PUFA (\%) & $6,24 \pm 2,71$ & $4,52 \pm 2,08$ & 0,046 \\
Serat total $(\mathrm{g})$ & $24,36 \pm 15,32$ & $19,63 \pm 8,84$ & 0,474 \\
\hline
\end{tabular}

Distribusi tingkat asupan meliputi asupan karbohidrat, lemak total, lemak jenuh, kolesterol,

MUFA, PUFA dan serat total dapat dilihat pada tabel 5.

Tabel 5. Distribusi tingkat asupan meliputi asupan karbohidrat, lemak total, lemak jenuh, kolesterol, MUFA, PUFA dan serat total

\begin{tabular}{llcc}
\hline \multirow{2}{*}{ Asupan zat gizi } & Vegan $(\mathrm{n}=19)$ & Non-vegan $(\mathrm{n}=19)$ \\
\cline { 2 - 4 } & & $\mathrm{n}(\%)$ & $\mathrm{n}(\%)$ \\
\hline Karbohidrat & Baik $(\leq 60 \%)$ & $2(10,5)$ & $2(10,5)$ \\
& Lebih $(>60 \%)$ & $17(89,5)$ & $17(89,5)$ \\
\hline Lemak total & Kurang $(<25 \%)$ & $16(84,2)$ & $17(89,5)$ \\
& Baik $(25-35 \%)$ & $3(15,8)$ & $2(10,5)$ \\
& Lebih $(>35 \%)$ & 0 & 0 \\
\hline \multirow{2}{*}{ Lemak jenuh } & Baik $(<7 \%)$ & $11(42,1)$ & $4(21,1)$ \\
& Lebih $(\geq 7 \%)$ & $19(100)$ & $15(78,9)$ \\
\hline Kolesterol & Baik $(<200 \mathrm{mg})$ & 0 & $18(94,7)$ \\
& Lebih $(\geq 200 \mathrm{mg})$ & $19(100)$ & $1(5,3)$ \\
\hline MUFA & Kurang $(<20 \%)$ & 0 & $19(100)$ \\
& Baik $(\geq 20 \%)$ & $18(94,7)$ & 0 \\
\hline PUFA & Kurang $(<10 \%)$ & $1(5,3)$ & $19(100)$ \\
& Baik $(\geq 10 \%)$ & $12(63,2)$ & 0 \\
\hline \multirow{2}{*}{ Serat total } & Kurang $(<25 \mathrm{~g})$ & $2(10,5)$ & $16(84,2)$ \\
& Baik $(25-30 \mathrm{~g})$ & $5(26,3)$ & $2(1,3)$ \\
& Lebih $(>30 \mathrm{~g})$ & & $2(10,5)$ \\
\hline
\end{tabular}

Rerata konsumsi karbohidrat kelompok vegan $68,16(8,1) \%$ dan lemak total 18,74 (6) \% sedangkan rerata konsumsi karbohidrat kelompok non-vegan 70,26 $(7,32) \%$ serta lemak total 17,84 $(5,79) \%$. Asupan lemak jenuh pada kedua kelompok cukup tinggi dengan nilai maksimum $16,74 \%$ pada kelompok vegan dan $20,55 \%$ pada kelompok non-vegan. Asupan kolesterol pada kedua kelompok sangat baik tetapi hanya satu orang dari kelompok non-vegan yang memiliki asupan kolesterol berlebih.yaitu sebesar 210,2 mg.
Asupan MUFA, PUFA dan serat total pada kedua kelompok tergolong kurang tetapi hanya satu orang pada kelompok vegan dengan asupan PUFA yang baik sebesar $13,67 \%$ serta terdapat lima orang dari kelompok vegan yang memiliki asupan serat total berlebih. Dari semua asupan zat gizi tersebut, terdapat perbedaan bermakna asupan kolesterol dan PUFA antara vegan dan non-vegan $(p<0,05)$.

Kadar Kolesterol Total dan Trigliserida Subjek Distribusi kadar kolesterol total subjek dapat dilihat pada tabel 6. 
Tabel 6. Distribusi kadar kolesterol total subjek berdasarkan tipe vegetarian

\begin{tabular}{lccc}
\hline \multirow{2}{*}{$\begin{array}{l}\text { Kategori kadar kolesterol } \\
\text { total }\end{array}$} & Vegan $(\mathrm{n}=19)$ & Non-vegan $(\mathrm{n}=19)$ & \multirow{2}{*}{$p$ value } \\
\cline { 2 - 3 } & $\mathrm{n}(\%)$ & $\mathrm{n}(\%)$ & 0,073 \\
Diinginkan $(<200 \mathrm{mg} / \mathrm{dl})$ & $15(78,9)$ & $11(57,9)$ & \\
$\begin{array}{l}\text { Batas tinggi }(200-239 \\
\mathrm{mg} / \mathrm{dl})\end{array}$ & $3(15,8)$ & $5(26,3)$ & \\
Tinggi $(\geq 240 \mathrm{mg} / \mathrm{dl})$ & $1(5,3)$ & $3(15,8)$ & \\
\hline
\end{tabular}

Rerata kadar kolesterol total $161.937 \pm$ 44.14 pada kelompok vegan dan $187.579 \pm 41.48$ pada non-vegan. Satu orang vegan dan tiga orang non-vegan memiliki kadar kolesterol total yang tinggi. Berdasarkan uji independent t-test (karena data berdistribusi normal) tidak terdapat perbedaan yang bermakna kadar kolesterol total antara kelompok vegan dan non-vegan $(p>0,05)$.

Distribusi kadar trigliserida subjek dapat dilihat pada tabel 7.

Tabel 7. Distribusi kadar trigliserida subjek berdasarkan tipe vegetarian

\begin{tabular}{lccc}
\hline \multirow{2}{*}{ Kategori kadar trigliserida } & Vegan $(\mathrm{n}=19)$ & Non-vegan $(\mathrm{n}=19)$ & \multirow{2}{*}{$p$ value } \\
\cline { 2 - 3 } & $\mathrm{n}(\%)$ & $\mathrm{n}(\%)$ & 0,884 \\
Normal $(<150 \mathrm{mg} / \mathrm{dl})$ & $17(89,5)$ & $17(89,5)$ & \\
Batas tinggi $(150-199$ & $2(10,5)$ & $2(10,5)$ & \\
mg/dl) & & & \\
Tinggi $(200-499 \mathrm{mg} / \mathrm{dl})$ & 0 & 0 & \\
Sangat tinggi $(\geq 500 \mathrm{mg} / \mathrm{dl})$ & 0 & 0 & \\
\hline
\end{tabular}

Sebagian besar subjek $(89,5 \%)$ memiliki kadar trigliserida yang normal pada masing-masing kelompok. Rerata kadar trigliserida vegan 84,66 \pm $40,43 \mathrm{mg} / \mathrm{dl}$ sedangkan non-vegan $86,16 \pm 45,40$ $\mathrm{mg} / \mathrm{dl}$. Nilai minimum kadar trigliserida pada kelompok vegan sebesar 42 mg/dl, maksimum 189 $\mathrm{mg} / \mathrm{dl}$ dengan median sebesar $71 \mathrm{mg} / \mathrm{dl}$, sedangkan pada kelompok non-vegan nilai minimum kadar trigliserida $31 \mathrm{mg} / \mathrm{dl}$, maksimum $171 \mathrm{mg} / \mathrm{dl}$ dengan median sebesar $78 \mathrm{mg} / \mathrm{dl}$. Berdasarkan uji MannWhiteney (karena data berdistribusi tidak normal) tidak terdapat perbedaan yang bemakna kadar trigliserida antara kelompok vegan dan non-vegan $(\mathrm{Z}=-0.146 ; \mathrm{p}>0,05)$.

Usia, lama menjadi vegetarian, aktivitas fisik, IMT dan asupan zat gizi (karbohidrat, lemak total, lemak jenuh, kolesterol, MUFA, PUFA dan serat total) merupakan variabel kontrol untuk melihat perbedaan kadar kolesterol total dan trigliserida. Oleh karena itu dilakukan analisis bivariat untuk melihat perbedaan kadar kolesterol total dan trigliserida berdasarkan variabel-variabel kontrol tersebut pada kelompok vegan dan nonvegan. Hasil uji beda dapat dilihat pada tabel 8 .

Tabel 8. Hasil uji beda kadar kolesterol total dan trigliserida subjek berdasarkan variabel-variabel kontrol

\begin{tabular}{lcc}
\hline \multirow{2}{*}{ Variabel kontrol } & \multicolumn{2}{c}{$p$ value } \\
\cline { 2 - 3 } & Kolesterol Total & Trigliserida \\
\hline Usia** & $0,035^{*}$ & $0,044^{*}$ \\
Lama menjadi vegetarian & 0,232 & 0,341 \\
IMT** & 0,832 & 0,445 \\
Aktivitas fisik & 0,540 & 0,160 \\
Asupan karbohidrat (\%)** & 0,911 & 0,288 \\
Asupan lemak total (\%)** & 0,929 & 0,376 \\
Asupan lemak jenuh (\%) & 0,875 & 0,536 \\
Asupan kolesterol (mg) & 0,540 & 0,832 \\
Asupan MUFA (\%) & 0,490 & 0,168 \\
Asupan PUFA (\%) & 0,730 & 0,154 \\
Asupan serat total (g) & 0,925 & 0,419 \\
\hline
\end{tabular}

Ket: * signifikan, ** uji independent t-test 
Berdasarkan uji independent t-test untuk data berdistribusi normal dan Mann-Whitney untuk data berdistribusi tidak normal, diketahui tidak terdapat perbedaan kadar kolesterol total berdasarkan lama menjadi vegetarian, IMT, aktivitas fisik dan asupan zat gizi (karbohidrat, lemak total, lemak jenuh, kolesterol, MUFA, PUFA dan serat total) serta terdapat perbedaan kadar kolesterol total berdasarkan usia $(p<0,05)$. Rerata usia subjek yang memiliki kadar kolesterol total normal $(<200 \mathrm{mg} / \mathrm{dl})$ adalah $37,08 \pm 13,67$ sedangkan usia subjek yang memiliki kadar kolesterol total tidak normal $(\geq 200 \mathrm{mg} / \mathrm{dl})$ yaitu $47,42 \pm 13,13$.

Berdasarkan uji independent t-test untuk data berdistribusi normal dan Mann-Whitney untuk data berdistribusi tidak normal, diketahui tidak terdapat perbedaan kadar trigliserida berdasarkan lama menjadi vegetarian, IMT, aktivitas fisik dan asupan zat gizi (karbohidrat, lemak total, lemak jenuh, kolesterol, MUFA, PUFA dan serat total) serta terdapat perbedaan kadar trigliserida berdasarkan usia $(p<0,05)$. Rerata usia subjek yang memiliki kadar trigliserida normal $(<150 \mathrm{mg} / \mathrm{dl})$ adalah 38,59 $\pm 13,6$ sedangkan usia subjek yang memiliki kadar trigliserida tidak normal $(\geq 150$ $\mathrm{mg} / \mathrm{dl}$ ) yaitu 55,25 $\pm 10,78$.

Perbedaan Kadar Kolesterol Total dan Kadar Trigliserida pada Vegetarian Vegan dan Nonvegan Setelah Dikontrol dengan Usia

Berdasarkan hasil analisis bivariat diketahui bahwa usia merupakan variabel kontrol yang mempengaruhi adanya perbedaan kadar kolesterol total dan trigliserida. Oleh karena itu dilakukan analisis multivariat untuk melihat perbedaan kadar kolesterol total dan trigliserida antara vegetarian vegan dan non-vegan yang dikontrol dengan usia. Tabel multivariat hasil pengujian ANCOVA dapat dilihat pada tabel 9.

Tabel 9. Hasil uji ANCOVA

Adjusted $R$ Squared = 0,154 untuk kolesterol total dan adjusted $R$ Squared = 0,284 untuk trigliserida

\begin{tabular}{llc}
\hline Variabel & & $p$ value \\
\hline Tipe vegetarian & Kadar kolesterol total & 0,949 \\
& Kadar trigliserida & 0,476 \\
\hline Usia & Kadar kolesterol total & $0,008^{*}$ \\
& Kadar trigliserida & $0,003^{*}$ \\
\hline
\end{tabular}

Ket: * signifikan

Berdasarkan pengujian ANCOVA, variabel usia sebagai variabel kontrol diketahui signifikan terhadap perbedaan kadar kolesterol total dan trigliserida antara vegetarian vegan dan non-vegan. Sebesar 15,4\% variabel tipe vegetarian dan usia memberikan kontribusi pada kadar kolesterol total serta sebesar $28,4 \%$ variabel tipe vegetarian dan usia memberikan kontribusi pada kadar trigliserida. Dapat disimpulkan bahwa perbedaan kolesterol total dan trigliserida antara kelompok vegan dan non-vegan lebih bermakna berdasarkan variabel usia $(p<0,05)$, sedangkan kolesterol total dan trigliserida tidak menunjukkan perbedaan yang signifikan berdasarkan tipe vegetarian $(\mathrm{p}>0,05)$.

\section{Perilaku Makan Subjek}

Pada penelitian ini dilakukan pula wawancara mendalam terhadap 14 subjek (8 subjek vegan dan 6 subjek non-vegan) mengenai perilaku makan. Sebagian besar subjek mengatakan alasan menjadi vegetarian adalah karena agama, moral dan etika. Alasan agama merupakan alasan awal mula subjek menjadi vegetarian karena sebagian besar subjek beragama Buddha yang menganjurkan setiap umatnya untuk menghindari makanan yang berasal dari hewani. Subjek berpendapat bahwa hewan adalah makhluk hidup sama seperti manusia yang dapat merasakan sakit. Beberapa di antara subjek pernah melihat film dokumenter mengenai proses hewan ternak sebelum disembelih hingga menjadi potonganpotongan daging yang siap dijual ke konsumen dan proses tersebut membuat mereka sadar bahwa hewan seharusnya diperlakukan dengan baik sehingga mereka berkomitmen tidak akan makan produk hewani lagi. Selain alasan-alasan tersebut, tidak bisa dipungkiri bahwa kesehatan juga merupakan salah satu alasan subjek menjalani diet vegetarian. Informasi-informasi mengenai kesehatan dan gizi vegetarian didapatkan melalui seminar-seminar yang diselenggarakan IVS. Subjek merasa jauh lebih sehat dan fit setelah menjadi vegetarian tetapi ada juga yang merasa tidak ada perubahan sebelum maupun setelah menjadi vegetarian serta ada yang merasa jiwanya lebih tenang karena tidak membunuh hewan untuk 
dimakan dagingnya. Selain subjek, anggota keluarga lainnya (orangtua, suami, anak dan saudara) juga menjadi vegetarian. Ada beberapa subjek yang menyatakan bahwa alasan mereka menjadi vegetarian adalah karena mengikuti orangtua ataupun anak yang lebih dulu menjalaninya. Bahkan ada subjek yang merasa bertanggungjawab terhadap kesehatan keluarganya sehingga suami dan anak-anaknya diarahkan untuk menjadi vegetarian dan akhirnya satu keluarga tersebut memulai menjadi vegetarian pada waktu yang bersamaan.

Sebelum menjadi vegan, sebagian besar subjek merupakan lakto-ovo vegetarian selama bertahun-tahun tetapi ada pula subjek yang langsung memilih menjadi vegan. Pada kelompok non-vegan juga sudah menjalani dietnya selama > 11 tahun bahkan ada yang $>50$ tahun. Hal tersebut membuat mereka tidak tertarik untuk mengkonsumsi produk hewani lagi bahkan saat diundang ke acara teman yang bukan vegetarian, subjek akan makan makanan vegetarian yang memang sudah disiapkan oleh tuan rumah tetapi jika tidak ada makanan vegetarian maka subjek lebih memilih tidak makan di acara tersebut, ada yang sudah makan sebelum pergi dan ada pula yang membawa bekal makanan dari rumah untuk dimakan di acara tersebut. Subjek lebih memilih makan masakan rumah tetapi pada saat pergi ke luar rumah ataupun ke luar kota subjek akan memilih restoran vegetarian yang memang sudah dipercaya bahwa restoran tersebut benar-benar hanya menyajikan makanan vegetarian. Jika subjek tidak menemukan restoran vegetarian, mereka terpaksa makan di restoran umum tetapi tetap akan meminta dibuatkan makanan vegetarian dan untuk makanan berkuah subjek akan selalu bertanya bahan pembuatan kaldunya serta meminta sayuran sebagai kaldunya. Subjek menyatakan saat mencium bau daging mereka merasa baunya amis sehingga mual dan ingin muntah jadi sangat tidak mungkin untuk mencoba kembali makanan tersebut. Subjek lain menyatakan bahwa sejak kecil sudah tertanam dalam hati produk-produk hewani tersebut bukanlah makanannya sehingga sampai kapanpun tidak akan pernah mau mencoba makanan itu.

Sejak menjadi vegetarian, subjek akan mencari bahan makanan lain dari nabati yang dapat menggantikan daging dan produk hewani lainnya. Bahan makanan tersebut antara lain tempe, tahu, jamur, kacang-kacangan dan gluten. Gluten merupakan daging imitasi yang terbuat dari tepung. Beberapa subjek jarang mengkonsumsi gluten dengan berbagai alasan yaitu tidak suka rasanya, mengandung pengawet dan takut ada campuran putih telur di dalamnya. Satu subjek menyatakan bahwa dia hanya akan mengkonsumsi gluten yang dibuat oleh ayahnya sendiri karena tahu dengan jelas tidak akan ada campuran putih telurnya ataupun produk hewani lainnya. Beberapa subjek mengkonsumsi gluten hanya sebagai variasi agar tidak bosan terutama bagi anak-anaknya yang masih kecil.

Tiga cara pengolahan makanan yang sering subjek lakukan yaitu makanan akan ditumis, direbus dan digoreng tetapi ada pula subjek yang lebih memilih untuk merebus dan mengukus makanannya. Sayuran selalu ada setiap kali mereka makan dengan berbagai variasi menu dan porsi sayur yang dimakan lebih banyak dibandingkan saat belum menjadi vegetarian. Konsumsi buah tidak sesering sayur yang setiap kali makan selalu ada. Beberapa subjek mengkonsumsi buah setiap hari karena sangat menyukai buah tetapi ada pula yang menyatakan tidak terlalu menyukai buah. Subjek non-vegan menyatakan sudah tidak mengkonsumsi susu dan telur secara utuh serta menghindari roti / kue yang masih menggunakan susu dan telur sebagai bahannya. Namun, bagi para biarawati non-vegan tidak mungkin menolak / membuang roti dan kue pemberian umatnya sehingga mereka tetap memakannya meskipun mereka mengetahui bahwa roti dan kue tersebut masih mengandung susu / telur di dalamnya. Sebaliknya, subjek vegan lebih memilih membuat roti dan kue sendiri. Mereka mengganti telur dengan tahu sutra sebagai perekat.

\section{PEMBAHASAN \\ Karakteristik Subjek Penelitian}

Jenis kelamin dan usia merupakan beberapa faktor yang tidak dapat diubah yang memberikan pengaruh terhadap perubahan profil lipid. Kejadian PJK akan meningkat seiring bertambahnya usia baik pada pria maupun wanita. Studi yang dilakukan pada 178 wanita sehat dan non-obese diketahui bahwa wanita yang berusia 20-35 tahun memiliki kadar profil lipid lebih rendah dibandingkan wanita berusia $>50$ tahun. ${ }^{19}$ Hal tersebut disebabkan karena wanita pada usia 20-35 tahun belum mengalami menopause. Hormon estrogen pada wanita premenopause memiliki efek protektif terhadap perubahan profil lipid tetapi penurunan hormon estrogen yang disebabkan oleh menopause akan meningkatkan risiko kejadian PJK terutama jika sudah menginjak usia 55 tahun. ${ }^{9,10}$ Penelitian lain menunjukkan 
bahwa wanita cenderung memiliki komposisi lemak tubuh yang tinggi dibanding pria pada kelompok usia yang sama. ${ }^{20}$ Distribusi lemak tubuh terutama di area jaringan adiposa viseral, dapat mempengaruhi perubahan profil lipid darah. ${ }^{19,21}$ Oleh karena itu, NCEP menyarankan bahwa pemeriksaan kadar lipid dan lipoprotein darah dimulai pada usia 20 tahun sehingga dapat dilakukan upaya pencegahan primer terhadap beberapa faktor risiko kejadian PJK yang sudah dideteksi lebih dini. ${ }^{9}$ Paparan di atas merupakan alasan yang melatarbelakangi jenis kelamin wanita dipilih sebagai subjek pada penelitian ini.

Dari 38 subjek, sebagian besar beragama Buddha. Agama Buddha memang menganjurkan umatnya untuk menjadi vegetarian yang bertujuan untuk pemurnian diri. ${ }^{22}$ Di samping itu, kesadaran menjaga kesehatan juga merupakan salah satu faktor subjek memilih menjadi vegetarian. Hal tersebut didukung dengan tingkat pendidikan yang tinggi yaitu > 50\% subjek pada masing-masing kelompok berpendidikan akademi / perguruan tinggi. Pendidikan sangat erat kaitannya dengan pengetahuan. Pengetahuan berperan penting dalam perilaku yang berkaitan dengan kesehatan. Perilaku yang didasari oleh pengetahuan akan dapat bertahan lebih lama dibandingkan dengan perilaku yang tidak didasari oleh pengetahuan. ${ }^{23}$ Pengetahuan subjek tidak hanya didapatkan dari pendidikan tetapi juga dari seminar-seminar mengenai gizi vegetarian yang diselenggarakan oleh IVS.

\section{Perbedaan Kadar Kolesterol Total dan Trigliserida Subjek Penelitian}

Pada penelitian De Biase et. al tanpa membedakan jenis kelamin dan rerata subjek pada masing-masing kelompok berada di bawah 40 tahun, diketahui bahwa tiga kelompok vegetarian (vegan, lakto vegetarian dan lakto-ovo vegetarian) memiliki kadar kolesterol total dan trigliserida yang rendah dibandingkan non-vegetarian. Vegan merupakan kelompok yang memiliki kadar kolesterol total dan trigliserida terendah. ${ }^{12}$ Penelitian tersebut didukung oleh penelitian lain yang menunjukan adanya perbedaan yang signifikan kadar kolesterol total dan trigliserida antara vegetarian dan non-vegetarian dengan rerata usia subjek di bawah 40 tahun. ${ }^{11}$ Akan tetapi pada penelitian ini menunjukkan bahwa tidak terdapat perbedaan yang signifikan kadar kolesterol total dan trigliserida antara vegan dan non-vegan. Hal tersebut mungkin disebabkan rerata usia subjek non-vegan lebih tinggi $(41,42 \pm 13,5)$ dibandingkan vegan $(39,26 \pm 15,14$ dan $41,42 \pm$
13,5). Selain itu, subjek yang dipilih dalam penelitian ini hanya wanita sehingga faktor jenis kelamin tersebut mengakibatkan hasil penelitian ini tidak konsisten dengan beberapa penelitian sebelumnya. Namun, sesuai dengan penelitian sebelumnya yang mengungkapkan bahwa kadar kolesterol total dan trigliserida pada vegan lebih rendah dibandingkan non-vegan.

Pada penelitian De Biase et. al juga diketahui bahwa hanya variabel usia yang memiliki pengaruh signifikan pada kadar kolesterol total dan trigliserida dibandingkan dengan variabel jenis kelamin. ${ }^{12}$ Berdasarkan analisis multivariat, diketahui bahwa variabel usia merupakan satusatunya variabel kontrol yang dapat menunjukkan perbedaan yang signifikan kadar kolesterol total dan trigliserida. Studi yang dilakukan De Nino pada 178 wanita sehat dan non-obese dengan subjek berusia 20-50 tahun lebih banyak daripada subjek berusia $>50$ tahun, juga mengemukakan bahwa perubahan kadar kolesterol dan trigliserida dipengaruhi oleh usia, di mana pertambahan usia akan meningkatkan kadar kolesterol total dan trigliserida. ${ }^{19}$ Selain faktor usia, perubahan profil lipid darah juga dipengaruhi oleh penurunan hormon estrogen pada wanita usia tua dan yang sudah mengalami menopause. ${ }^{9,10}$ Studi yang dilakukan pada wanita produktif dan menopause, diketahui bahwa wanita yang sudah mengalami menopause (46-55 tahun) cenderung memiliki kadar kolesterol total dan trigliserida yang tinggi dibandingkan usia produktif (16-45 tahun). ${ }^{24} \mathrm{Hal}$ tersebut dapat memberikan penjelasan terkait hasil penelitian ini, di mana subjek yang memiliki kadar kolesterol total tinggi $(\geq 240 \mathrm{mg} / \mathrm{dl})$ dan trigliserida dalam batas tinggi (150-199 $\mathrm{mg} / \mathrm{dl})$ berusia $>50$ tahun. Sebanyak 21 subjek $(80,77 \%)$ dari 26 total subjek vegetarian yang memiliki kadar kolesterol total normal $(<200 \mathrm{mg} / \mathrm{dl})$ dan 25 subjek $(73,53 \%)$ dari 34 total subjek vegetarian yang memiliki kadar trigliserida normal $(<150 \mathrm{mg} / \mathrm{dl})$ berada dalam usia produktif.

Lama vegetarian berpengaruh pada rendahnya kadar kolesterol total. Diet vegetarian yang dijalani $\geq 12$ tahun memiliki kadar kolesterol total lebih rendah dibandingkan diet vegetarian yang dijalani 6-11 tahun. ${ }^{11}$ Dari keempat subjek (satu subjek vegan dan tiga subjek non-vegan) yang memiliki kadar kolesterol total tinggi, hanya satu subjek yang menjalani diet vegetarian < 6 tahun dengan kadar kolesterol paling tinggi di antara yang lain. Namun, lama vegetarian tidak berpengaruh signifikan terhadap rendahnya kadar trigliserida. Kadar trigliserida terendah dimiliki 
oleh subjek yang menjalani diet vegetarian $<6$ tahun sedangkan diet vegetarian selama 6-11 tahun diketahui memiliki kadar trigliserida tertinggi. ${ }^{11}$ Pada penelitian ini empat subjek (masing-masing dua subjek pada tiap kelompok) memiliki kadar trigliserida dalam batas tinggi dan keempatnya menjalani diet vegetarian $>6$ tahun.

Pada penelitian ini diketahui terdapat perbedaan yang signifikan IMT antara vegan dan non-vegan. Rerata IMT pada vegan lebih rendah dibandingkan non-vegan. Seseorang dengan IMT overweight ataupun obese memiliki faktor risiko PJK cukup tinggi yang meliputi tingginya kadar kolesterol total dan trigliserida. ${ }^{9}$ Dari hasil penelitian diketahui tiga subjek non-vegan yang memiliki kadar trigliserida dalam batas tinggi $(150-199 \mathrm{mg} / \mathrm{dl})$ juga memiliki IMT overweight dan obesitas sedangkan hanya satu orang nonvegan yang memiliki kadar kolesterol total tinggi dengan IMT overweight. Aktivitas fisik juga merupakan salah satu faktor yang dapat mempengaruhi kadar kolesterol total dan trigliserida. Rendahnya aktivitas fisik menurunkan energy expenditure dan berkontribusi terhadap obesitas yang berkaitan dengan faktor risiko lipid dan non-lipid. Dengan demikian, peningkatan aktivitas fisik akan dapat menurunkan IMT sehingga dapat memperbaiki profil lipid di antaranya penurunan kadar kolesterol total dan trigliserida. ${ }^{9}$ Namun, berdasarkan hasil penelitian diketahui aktivitas fisik antara vegan dan nonvegan tidak memiliki perbedaan dan tidak berpengaruh signifikan terhadap kadar kolesterol total maupun trigliserida.

Selain IMT dan aktivitas fisik, asupan zat gizi merupakan faktor yang dapat mempengaruhi kadar kolesterol total dan trigliserida. Asupan makan vegan tidak menyertakan produk hewani sama sekali. Hal tersebut berbeda dengan nonvegan yang masih mengkonsumsi produk hewani meliputi susu, telur dan produk olahannya. Telur dan produk susu merupakan sumber kolesterol dan lemak jenuh yang berasal dari makanan. Telur menyumbang 1/3 kolesterol dalam makanan. Asupan kolesterol meningkatkan rasio kolesterol total / HDL yang berpengaruh pada kadar kolesterol serum. Konsumsi makanan tinggi lemak jenuh akan menyebabkan peningkatan pada kadar kolesterol darah (hiperkolesterolemia), kejadian PJK dan kematian. Asupan karbohidrat, MUFA, PUFA dan serat total juga dapat mempengaruhi profil lipid darah. Asupan MUFA, PUFA dan serat total diketahui memiliki efek positif terhadap profil lipid darah. Dibandingkan dengan MUFA, subtitusi lemak jenuh dengan karbohidrat akan meningkatkan kadar trigliserida. Peningkatan kadar trigliserida akan berkurang saat karbohidrat dikonsumsi bersamaan dengan asupan tinggi serat. $^{9,10}$

Berdasarkan hasil penelitian, hanya asupan kolesterol dan PUFA yang berbeda signifikan antara vegan dan non-vegan. Namun, asupan zat gizi tersebut (karbohidrat, lemak total, lemak jenuh, kolesterol, MUFA, PUFA dan serat total) tidak berpengaruh signifikan terhadap kadar kolesterol total dan trigliserida. Hal tersebut mungkin disebabkan sebagian subjek non-vegan sudah tidak mengkonsumsi susu dan telur secara utuh, tetapi sesekali masih mengkonsumsi produk olahannya seperti roti, biskuit dan kue. Meskipun demikian, rerata asupan MUFA, PUFA dan serat total pada vegan lebih tinggi dibanding non-vegan. Sebaliknya, rerata asupan kolesterol dan lemak jenuh pada non-vegan lebih tinggi disbanding vegan. Pengolahan makanan dengan cara digoreng dapat memberikan kontribusi terhadap asupan lemak jenuh yang tinggi meskipun subjek nonvegan sudah tidak mengkonsumsi produk susu dan telur secara utuh.

\section{KETERBATASAN PENELITIAN}

Penelitian ini memiliki beberapa keterbatasan yaitu sulitnya mendapatkan subjek vegan sehingga peneliti harus mencari subjek vegan di kota yang berbeda. Hal tersebut menyebabkan pemeriksaan kadar kolesterol total dan trigliserida dilakukan oleh laboratorium klinik yang berbeda pula sehingga tidak menutup kemungkinan metode yang digunakan juga berbeda. Selain itu, perbedaan penafsiran instrumen penelitian (seperti kuesioner aktivitas fisik dan FFSQ) oleh enumerator dapat menyebabkan perbedaan dalam wawancara dengan responden.

\section{SIMPULAN}

Tidak terdapat perbedaan signifikan kadar kolesterol total dan trigliserida antara wanita vegetarian vegan dan non-vegan tetapi terdapat perbedaan signifikan IMT pada vegan dan nonvegan. Usia merupakan satu-satunya variabel kontrol yang berpengaruh pada kadar kolesterol total dan trigliserida baik pada vegan maupun nonvegan. Kadar kolesterol total dan trigliserida kelompok vegan lebih rendah dibandingkan nonvegan. Sejak menjadi vegetarian, baik pada kelompok vegan maupun non-vegan menyatakan tidak pernah dan tidak ingin lagi mengkonsumsi 
produk hewani dengan berbagai alasan antara lain merasa lebih sehat tanpa makan produk hewani, merasa bahwa produk hewani tersebut bukanlah 7 . makanannya dan merasa mual serta ingin muntah saat mencium bau amis dari produk hewani tersebut.

\section{SARAN}

Kadar kolesterol total yang tinggi dan trigliserida dalam batas tinggi ditemukan pada subjek vegan maupun non-vegan. Usia $>50$ tahun dan IMT overweight maupun obese perlu 10 diperhatikan karena hal tersebut merupakan faktor risiko peningkatan kadar kolesterol total dan trigliserida. Asupan zat gizi yang sesuai dengan rekomendasi NCEP ATP III dan peningkatan11. aktivitas fisik merupakan beberapa cara untuk memperoleh kadar kolesterol dan trigliserida dalam batas normal.

Bagi penelitian selanjutnya, diharapkan12. dapat membandingkan keempat profil lipid (kolesterol total, kolesterol LDL, kolesterol HDL dan trigliserida) tidak hanya pada wanita vegan dan non-vegan tetapi juga pada pria dengan 13 . menyertakan variabel yang belum diteliti seperti kandungan lemak tubuh di daerah jaringan adiposa viseral ataupun dengan desain penelitian lain yang memiliki jangka waktu cukup lama seperti case- 14 . control atau kohort.

\section{DAFTAR PUSTAKA}

15.

1. ADA Reports. Position of the American Dietetic Association and Dietitians of Canada: Vegetarian diets. J Am Diet Assoc. 2009;109:1266-1282.

2. Susianto. Analisis faktor-faktor yang berhubungan 16 . dengan IMT/U pada balita vegetarian lakto ovo dan non vegetarian di DKI Jakarta tahun 2008. [Tesis]. Jakarta: Universitas Indonesia. 2008. Available at http://gizi.net/makalah/download/tesis_susianto.pdf [accessed on February 17th, 2012].

3. Sabaté J, Ratzin-Turner RA, Brown JE. Vegetarian diet: descriptions and trends. In: Joan Sabaté, editor. Vegetarian nutrition. USA: CRC Press LLC; 2001. p 3-17.

4. Key TJ, Appleby PN. Vegetarianism, coronary risk factors, and coronary heart disease. In: Joan Sabaté, editor. Vegetarian Nutrition. USA: CRC Press LLC; 2001. p 33-48.

5. Mills PK. Vegetarian diets and cancer risk. In: Joan19. Sabaté, editor. Vegetarian Nutrition. USA: CRC Press LLC; 2001. p 55-86.

6. Rajaram S, Wien M. Vegetarian diets in the prevention of osteoporosis, diabetes, and20. neurological disorders. In: Joan Sabaté, editor.
Vegetarian nutrition. USA: CRC Press LLC; 2001. p 110-129.

7. Sabaté J, Blix G. Vegetarian diets and obesity prevention. . In: Joan Sabaté, editor. Vegetarian nutrition. USA: CRC Press LLC; 2001. p 91-105.

8. Craig WJ. Health effects of vegan diets. Am J Clin Nutr 2009; 89(suppl):1627S-33S.

9. National Cholesterol Education Program. Detection, evaluation, and treatment of high blood cholesterol in adult (Adult Treatment Panel III). Final report. National Institutes of Health-NIH Publication 2002; 106:3143.

Krummel DA. Medical nutrition therapy for cardiovascular disease. In: Mahan LK, Sylvia ES, editors. Krause's food, nutrition and diet therapy, $12^{\text {th }}$ edition. USA: Saunders. 2008. 32:833-860.

Yang SY et.al. Relationship of carotid intima-media thickness and duration of vegetarian diet in Chinese male vegetarians. Nutrition \& Metabolism 2011, 8:63.

De Biase SG, Fernandez SFC, Gianini RJ, Duarte JLG. Vegetarian Diet and Cholesterol and Triglycerides Levels. Arq bras Cardiol 2007;88(Pt 1):32-6.

Kim MK, Cho Sang Woon and Park Yoo Kyoung. Long-term vegetarians have low oxidative stress, body fat, and cholesterol levels. Nutr Res Pract 2012; 6(2): 155-161.

Sutiari NK. Konsumsi, status gizi, dan kesehatan masyarakat vegetarian dan nonvegetarian di Bali. [tesis].Bogor: IPB. 2008.

5eriemaeker $\mathrm{P}$ et al. Health aspects, nutrition and physical characteristics in matched samples of instutionalized vegetarian and non-vegetarian elderly (> 65 yrs). Nutrition \& Metabolism 2011, $8: 37$.

Miller $\mathrm{M}$ et.al. Triglycerides and Cardiovascular Disease : A Scientific Statement From the American Heart Association. Circulation 2011, 123:22922333.

17. WHO/IOTF/IASO. 2000. The Asia-Pacific perspective: Redefining Obesity and its treatment. Hong Kong: World Health Organization, International Obesity Task Force, International Association for the Study of Obesity.

18. International Physical Activity Questionnaire. Guidelines for data processing and analysis of the International Physical Activity Questionnaire (IPAQ). Short and Long Form. Revised November 2005. Available from : www.ipaq.ki.se.

De Nino WF et.al. Contribution of abdominal adiposity to age-related differences in insulin sensitivity and plasma lipids in health non obese women. Diabetes Care 2001;24:925-932.

Szymanska JO, Wozniak EH, Platkowska I, Malara M. Effect of age, gender, and physical activity on 
plasma lipid profile. Biomedical Human Kinetics 2011;3:1-5.

21. Miller WM, Janosz KEN, Lillystone M, Yanes J, McCoullough PA. Obesity and lipids. Current Cardiology Reports 2005;7:465-70.

22. Larsson CL, Johansson GK. Dietary intake and nutritional status of young vegans and omnivores in Sweden. Am J Clin Nutr 2002;76:100-6.

23. Soekidjo Notoatmodjo. Pendidikan perilaku kesehatan. Jakarta: Rhineka Cipta. 2003.p.215-8.

24. Bhagya V, Hemalatha NR, Veeranna HB, Banu V. Serum lipid profile in pubertal, reproductive and postmenopausal women. Int J Biol Med Res. 2011; 2(3): 639-642. 